\title{
Kinerja Pengawas Lembaga Perkreditan Desa dan Faktor yang Mempengaruhinya Dimoderasi Budaya Tri Hita Karana
}

\author{
I Gst Ayu Eka Damayanthi' \\ Fakultas Ekonomi dan Bisnis \\ Universitas Udayana, Indonesia
}

\author{
Ni K.Lely Aryani Merkusiwati² \\ Fakultas Ekonomi dan Bisnis \\ Universitas Udayana, Indonesia
}

\begin{abstract}
Surel : eka_damayanthi@unud.ac.id ABSTRAK

Penelitian ini dilakukan dengan mempertimbangkan ketidakkonsistenan hasil penelitian mengenai pengaruh independensi, profesionalisme dan sistem informasi akuntansi terhadap kinerja Badan Pengawas sebagai pengendali internal LPD dengan memoderasi budaya organisasi Tri Hita Karana. Sampel dalam penelitian ini berjumlah 35 LPD di Kota Denpasar. Metode pengumpulan data yang digunakan adalah kuesioner. Teknik analisis data yang digunakan dalam menguji hipotesis penelitian ini adalah regresi linier berganda. Hasil dari penelitian ini adalah bahwa independensi berpengaruh positif terhadap kinerja pengawas LPD, profesionalisme dan SIA tidak berpengaruh terhadap kinerja pengawas, budaya Tri Hita Karana mampu memoderasi dan memperkuat pengaruh independensi. terhadap kinerja kepegawaian LPD, dan budaya tri hita karena belum mampu memoderasi pengaruh profesionalisme dan BSM terhadap kinerja pengawas LPD di Kota Denpasar.
\end{abstract}

Kata Kunci: Kinerja Badan Pengawas LPD; Kemandirian; Profesionalisme; SIA; Budaya Tri Hita Karana.

\section{Performance Of Supervisors Of Village Credit Institutions And Factors Affecting It Moderated Culture Tri Hita Karana}$$
\text { ABSTRACT }
$$

This research was conducted by considering the inconsistency of research results regarding the influence of independence, professionalism and accounting information systems on the performance of the Supervisory Body as the internal controller of the LPD by moderating the organizational culture of Tri Hita Karana. The sample in this study amounted to 35 LPDs in Denpasar City. The data collection method used was a questionnaire. The data analysis technique used in testing the hypothesis of this study is multiple linear regression. The results of this study are that independence has a positive effect on the performance of LPD supervisors, professionalism and SIA have no effect on supervisor performance, the Tri Hita Karana culture is able to moderate and strengthen the influence of independence. on LPD staffing performance, and tri-black culture because it has not been able to moderate the influence of professionalism and BSM on the performance of LPD supervisors in Denpasar City.
\end{abstract}

Keywords: $\quad$ LPD Supervisory Body Performance; Independence; Professionalism; SIA; Tri Hita Karana Culture.

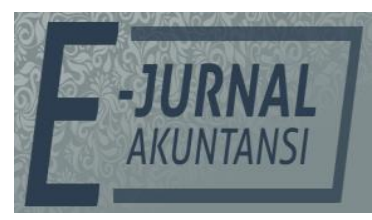

e-ISSN 2302-8556

Vol. 31 No. 4

Denpasar, April 2021

Hal. 937-954

DOI:

10.24843/EJA.2021.v31.i04.p11

PENGUTIPAN:

Damayanthi, I G.A.E., \&

Merkusiwati, N.L.A. (2021).

Kinerja Pengawas Lembaga

Perkreditan Desa dan Faktor yang Mempengaruhinya Dimoderasi Budaya Tri Hita Karana. E-Jurnal Akuntansi, 31(4), 937-954

RIWAYAT ARTIKEL:

Artikel Masuk: 14 Januari 2021 Artikel Diterima: 24 April 2021

Artikel dapat diakses : https://ojs.unud.ac.id/index.php/Akuntansi/index 


\section{PENDAHULUAN}

Lembaga Perkreditan Desa (LPD) menjelma jadi benteng ekonomi Bali. LPD telah eksis selama 35 tahun. LPD menghadapi berbagai macam tantangan. Terlebih di era globalisasi ini, ujian bagi LPD tentunya akan semakin besar. Keberadaan LPD di Kota Denpasar paling sedikit di Provinsi Bali, namun LPD di Kota Denpasar memiliki asset tertinggi. Aset yang tinggi sangat beresiko terhadap penyalahgunaan keuangan maka LPD memerlukan badan pengawas LPD yang bertanggung jawab mengawasi dan mengontrol aktivitas LPD (Maya dan Sumerta, 2019).

Badan pengawas LPD memiliki tugas atau tanggung jawab dalam mengawasi pelaksanaan kegiatan LPD. Apakah semua kebijakan yang ditetapkan telah dilaksanakan dengan tepat dan agar tidak terjadi penyimpangan dan kesalahan. Badan pengawas LPD memiliki fungsi audit dan melakukan pengawasan pada setiap pelaksanaan kegiatan LPD dalam Suartana (2009). LPD dalam melaksanakan kegiatan pengawasan dan menilai efektivitas pengendalian internal memerlukan badan pengawas yang harus memiliki sikap independen. Selain independen, seorang badan pengawas juga harus memiliki profesionalisme. Badan pengawas juga sebaiknya harus menguasai teknologi informasi. Sistem informasi akuntansi yang digunakan di LPD adalah Banking Smart System dengan jaringan Novell 5.0, dengan bantuan sistem yang berbasis teknologi individu diharapkan dapat menyelesaikan pekerjaannya dengan mudah, cepat dan akurat.

Beberapa penelitian telah dilakukan mengenai hubungan antara sikap independensi dan kinerja pengawas sebagai auditor internal tidak memperoleh hasil konsisten Putra \& Jati (2019), Murtini \& Juliarsa (2017), Widyantara et al., (2017), Arumsari et al., (2014) Yadnya \& Ariyanto (2017) Safitri (2014), Salju et al., (2014), dan Wijaya (2018). Penelitian yang hasilnya tidak konsisten berhubungan dengan profesionalisme terhadap kinerja pengawas antara lain dilakukan oleh Putra \& Jati (2019), Murtini \& Juliarsa (2017), Nugraha \& Ramantha (2015), Prabayanthi \& Widhiyani (2018), Kusnadi \& Suputra (2015), Fuad \& Trisnawati (2015). Penelitian yang menyatakan bahwa sistem informasi akuntansi berpengaruh terhadap kinerja karyawan dan dewan pengawas dengan hasil yang tidak konsisten dilakukan oleh Pratami \& Damayanthi (2018), Listiani (2017), Murni \& Juliarsa (2018) Arsiningsih, et al., (2015) Astuti \& Dharmadiaksa (2014), Pratama \& Suardikha (2013), Soudani (2012), Al-Eqab \& Adel (2013) Gunawan \& Tenaya (2017) serta Saraswati \& Damayanthi (2018).

Hasil Penelitian yang tidak konsistennya mengenai pengaruh sikap independensi, profesionalisme dan sistem informasi akuntansi terhadap kinerja pengawas sebagai pengendali internal LPD, maka diperkirakan terdapat variabel lain yang dapat memoderasi pengaruh tersebut. Variabel moderasi yang dipertimbangkan dalam penelitian ini adalah budaya berbasis Tri Hita Karana. Urgensi penelitian adalah bagaimana faktor independensi, profesionalisme, system informasi akuntansi berbasis IT mempengaruhi kinerja pengawas LPD dengan moderasi budaya Tri Hita Karana di kota Denpasar.

Menurut Lubis (2009:91), teori agensi didasarkan pada teori ekonomi. Dari sudut pandang teori agensi, prinsipal (pemilik atau manajemen puncak) membawahi agen (karyawan atau manajemen yang lebih rendah) untuk 
melaksanakan kinerja yang efisien. Berdasarkan teori agensi di dalam Lembaga Perkreditan Desa (LPD), yang bertindak sebagai pihak prinsipal adalah Desa Pekraman yang merupakan pemilik dari LPD tersebut dan yang bertindak sebagai pihak agen adalah pengurus LPD.

Teori sikap dan perilaku (theory of attitude and behavior) yang dikembangkan oleh Triandis (1980), menyatakan bahwa perilaku seseorang ditentukan oleh sikap yang terkait dengan apa yang orang-orang ingin lakukan serta terdiri dari keyakinan tentang konsekuensi dari melakukan perilaku, aturan-aturan sosial yang terkait dengan apa yang mereka pikirkan tentang mereka, dan kebiasaan yang terkait dengan apa yang mereka biasa lakukan (Swari \& Ramantha, 2013). Teori ini menjelaskan bagaimana perilaku badan pengawas LPD dengan adanya sikap independensi dan profesionalisme serta penguasain teknologi informasi mampu memengaruhi kinerja pengawas LPD dan juga efektivitas penerapan pengendalian internal LPD.

Goodhue \& Thompsom (1995) merupakan pelopor teori Technology to Performance Chain, mengenai pengaruh pemanfaatan teknologi informasi terhadap kinerja individual maupun perusahaan. Penelitian yang dilakukan oleh Murni \& Juliarsa (2018) dan Kasandra \& Juliarsa (2016) menyatakan bahwa suatu teknologi berdampak positif terhadap kinerja dengan adanya teknologi akan mendukung penyelesaian tugas setiap individu dan berdampak pada kinerja yang dihasilkan. Sikap independensi dirasa sangat penting dalam melaksanakan pengawasan yang efektif. Putra \& Jati (2019), Widyantara et al., (2017), Arumsari et al., (2014), Yadnya \& Ariyanto (2017), Winarsih \& Suardana (2018) dalam penelitiannya menunjukkan bahwa independensi berpengaruh positif kinerja pengawas LPD (Panureksa).

Badan pengawas internal harus memiliki sikap profesionalisme, karena pemeriksaan internal harus menggunakan keahlian dan ketelitian dalam menjalankan profesinya (Akmal, 2006). Dalam penelitian Putra \& Jati (2019), Murtini \& Juliarsa (2017) Nugraha \& Ramantha (2015) serta Prabayanthi \& Widhiyani (2018) membuktikan bahwa profesionalisme berpengaruh positif dan signifikan terhadap kinerja pengawas sebagai auditor internal.

Sistem informasi yang digunakan oleh LPD adalah Banking Smart System dengan jaringan Novell 5.0, dalam teori Technology to Performance Chain menyatakan bahwa sebuah teknologi akan berdampak terhadap kinerja jika digunakan oleh individual. Dalam penelitian yang dilakukan oleh Soudani (2012), Samuel (2013), Gupta et al., (2007), Kasandra \& Juliarsa (2016), Murni \& Juliarsa (2018), Rizaldi (2015), Astuti \& Darmadiaksa (2014), Pratami \& Damayanthi (2018) dan Listiana (2017) menyatakan bahwa sistem informasi akuntansi berpengaruh positif dan signifikan terhadap kinerja karyawan dan dewan pengawas.

Implementasi dari budaya Tri Hita Karana di sebuah LPD akan mendukung terciptanya keharmonisan pada setiap kegiatan bisnis yang ada didalamnya. Budaya Tri Hita Karana merupakan salah satu faktor yang mendukung berhasilnya penerapan sikap badan pengawas pada sebuah organisasi yang akan berdampak pada meningkatnya efektivitas pengendalian internal dan kinerja dari badan pengawas tersebut. Mercury \& Putri (2015) 
Sudiartini \& Mimba (2018) menunjukkan bahwa budaya Tri Hita Karana berpengaruh positif pada kinerja pengawas LPD.

Teori sikap dan perilaku (theory of attitude and behavior) menjelaskan sikap independen seorang auditor dalam penampilannya. Seorang auditor internal akan berperilaku independen dalam penampilannya, dimana seorang auditor dalam menjalankan tugasnya tidak dibenarkan memihak terhadap kepentingan apapun. Dalam proses pengawasannya, seorang badan pengawas dituntut memiliki sikap objektif dan integritas tinggi yang tercermin dalam sikap independensi (Putra \& Wisadha, 2012). Penjelasan tersebut juga sesuai dengan teori keagenan (agency theory), dimana auditor internal sebagai pihak ketiga yang menerima tugas dan tanggungjawab untuk dapat menyelesaikan permasalahan antara agen (agent) dan pemilik (principal), auditor dituntut untuk memiliki sikap independensi yang tinggi. Sikap independensi dirasa sangat penting dalam melaksanakan pengawasan yang efektif. Putra \& Jati (2019), Widyantara et al., (2017), Arumsari et al., (2014), Yadnya \& Ariyanto (2017), Winarsih \& Suardana (2018) dalam penelitiannya menunjukkan bahwa independensi berpengaruh positif kinerja badan pengawas LPD (Panureksa). Berdasarkan uraian tersebut, maka dapat dirumuskan hipotesis sebagai berikut.

$\mathrm{H}_{1}$ : Independensi berpengaruh positif terhadap kinerja badan pengawas LPD.

Hubungan antara profesional dengan kinerja badan pengawas LPD didasarkan pada keyakinan seseorang terhadap profesi badan pengawas yang akan mencerminkan suatu sikap profesionalisme dalam bekerja yang dapat memberikan motivasi untuk meningkatkan kinerjanya. Keyakinan tersebut sesuai dengan teori sikap dan perilaku (theory of attitude and behavior) yang menyatakan bahwa sikap merupakan suatu pernyataan evaluatif terhadap kondisi yang sedang dialami dan nantinya akan memberikan kecenderungan untuk bereaksi atau berperilaku baik itu positif maupun negatif. Dengan adanya keyakinan pada profesi tersebut, badan pengawas dapat memberikan motivasi untuk selalu memberikan hasil pekerjaan serta pertimbangan yang dapat dipertanggungjawabkan.

Sikap dan perilaku profesional adalah syarat utama bagi seseorang untuk menjadi badan pengawas disamping memiliki sikap disiplin, pengalaman, dan keahlian dalam menjalankan profesinya sebagai seorang badan pengawas. Menurut Futri dan Juliarsa (2014) sebagai seorang auditor, menjadi profesional adalah sebuah tanggung jawab individu untuk berperilaku yang lebih baik dari sekedar memenuhi undang-undang, kode etik, dan peraturan yang ada. Badan pengawas internal harus memiliki sikap profesionalisme, karena pemeriksaan internal harus menggunakan keahlian dan ketelitian dalam menjalankan profesinya (Akmal, 2006). Dalam penelitian Putra \& Jati (2019), Murtini \& Juliarsa (2017) Nugraha \& Ramantha (2015) serta Prabayanthi \& Widhiyani (2018) membuktikan bahwa profesionalisme berpengruh positif dan signifikan terhadap kinerja badan pengawas sebagai auditor interal. Berdasarkan uraian, maka dapat dirumuskan hipotesis sebagai berikut.

$\mathrm{H}_{2}$ : Profesionalisme berpengaruh positif pada kinerja badan pengawas LPD.

Sistem informasi yang digunakan oleh LPD adalah Banking Smart System dengan jaringan Novell 5.0, dalam teori Technology to Performance Chain menyatakan bahwa sebuah teknologi akan berdampak terhadap kinerja jika 
digunakan oleh individual. Astuti (2014) menyatakan sistem informasi dapat dimanfaatkan oleh banyak pihak untuk mencapai keunggulan perusahaan melalui kecepatan, fleksibilitas, integrasi, dan keakuratan informasi yang dihasilkan. Sistem informasi akuntansi mampu memberikan kesempatan bagi manajer untuk meningkatkan efisiensi dan efektivitas dalam pengambilan keputusan. Sistem informasi akuntansi juga dapat mempermudah pemeriksaan dan pengawasan LPD dengan asumsi dewan pengawas harus menguasai SIA di LPD tersebut. Dalam penelitian yang dilakukan oleh Soudani (2012), Samuel (2013), (Gupta et al., (2007), Kasandra \& Juliarsa (2016), Murni \& Juliarsa (2018), Rizaldi (2015), Astuti \& Darmadiaksa (2014), Pratami \& Damayanthi (2018) dan Listiana (2017) menyatakan bahwa sistem informasi akuntansi berpengaruh positif dan signifikan terhadap kinerja karyawan dan dewan pengawas. Berdasarkan uraian, maka hipotesis penelitian adalah sebagai berikut.

$\mathrm{H}_{3}$ : Sistem informasi akuntansi berpengaruh kinerja Badan pengawas LPD.

Budaya merupakan proses pemrograman pikiran kolektif yang membedakan anggota satu kelompok atau kategori orang-orang dari lainnya. Salah satu budaya kearifan lokal adalah budaya Tri Hita Karana dapat diartikan sebagai tiga penyebab kebahagiaan. Oleh karena itu, filosofi Tri Hita Karana ini dapat memberikan panduan mengenai bagaimana manusia harus bersikap terhadap tiga hal, yaitu parahyangan, pawongan, dan palemahan (Surya et al., 2014). Implementasi dari budaya Tri Hita Karana di sebuah LPD akan mendukung terciptanya keharmonisan pada setiap kegiatan bisnis yang ada didalamnya. Budaya Tri Hita Karana merupakan salah satu faktor yang mendukung berhasilnya penerapan sikap badan pengawas pada sebuah organisasi yang akan berdampak pada meningkatnya efektivitas pengendalian internal dan kinerja dari badan pengawas tersebut.

Mercury \& Putri (2015), Sudiartini \& Mimba (2018) menunjukkan bahwa budaya Tri Hita Karana berpengaruh positif pada kinerja badan pengawas LPD. Menurut penelitian Mercury \& Putri (2015) menemukan hasil bahwa budaya Tri Hita Karana mampu memoderasi hubungan tekanan waktu (memperkuat) terhadap kinerja auditor di Kantor Akuntan Publik Provinsi Bali.

$\mathrm{H}_{4}$ : Budaya Tri Hita Karana memperkuat pengaruh independensi terhadap kinerja badan pengawas LPD.

Menurut penelitian Mulyawan et al., (2017) menunjukkan bahwa budaya Tri Hita Karana memperkuat pengaruh dari good corporate governance pada kinerja LPD. Sistem informasi akuntansi berguna untuk membantu para karyawan dalam suatu perusahaan untuk ngambil keputusan yang bermanfaat, dalam teori Technology to Performance Chain menyatakan bahwa sebuah teknologi akan sangat berdampak pada kinerja.

$\mathrm{H}_{5}$ : Budaya Tri Hita Karana memperkuat pengaruh profesionalisme terhadap kinerja badan pengawas LPD.

Budaya organisasi diperlukan dalam mengambil keputusan karena budaya organisasi memiliki fungsi untuk membentuk aturan atau pedoman berfikir dan bertindak dalam mencapai tujuan yang telah ditetapkan. Hal ini di dukung oleh penelitian yang dilakukan oleh Soudani (2012), Grande et al., (2011), Pratami \& Damayanthi (2018) dan Murni \& Juliarsa (2018) yang menyatakan bahwa sistem informasi akuntansi melalui budaya organisasi berpengaruh positif dan 
signifikan terhadap kinerja karyawan. Berdasarkan uraian, maka hipotesis yang dapat dirumuskan adalah sebagai berikut.

$\mathrm{H}_{6}$ : Budaya Tri Hita Karana memperkuat pengaruh SIA terhadap kinerja badan pengawas LPD.

\section{METODE PENELITIAN}

Jumlah variabel yang teridentifikasi dan berdasarkan kerangka berpikir, kemudian disusun konsep yang menjelaskan hubungan antar variabel dalam penelitian ini. Konsep tersebut dapat disajikan dalam gambar 1.

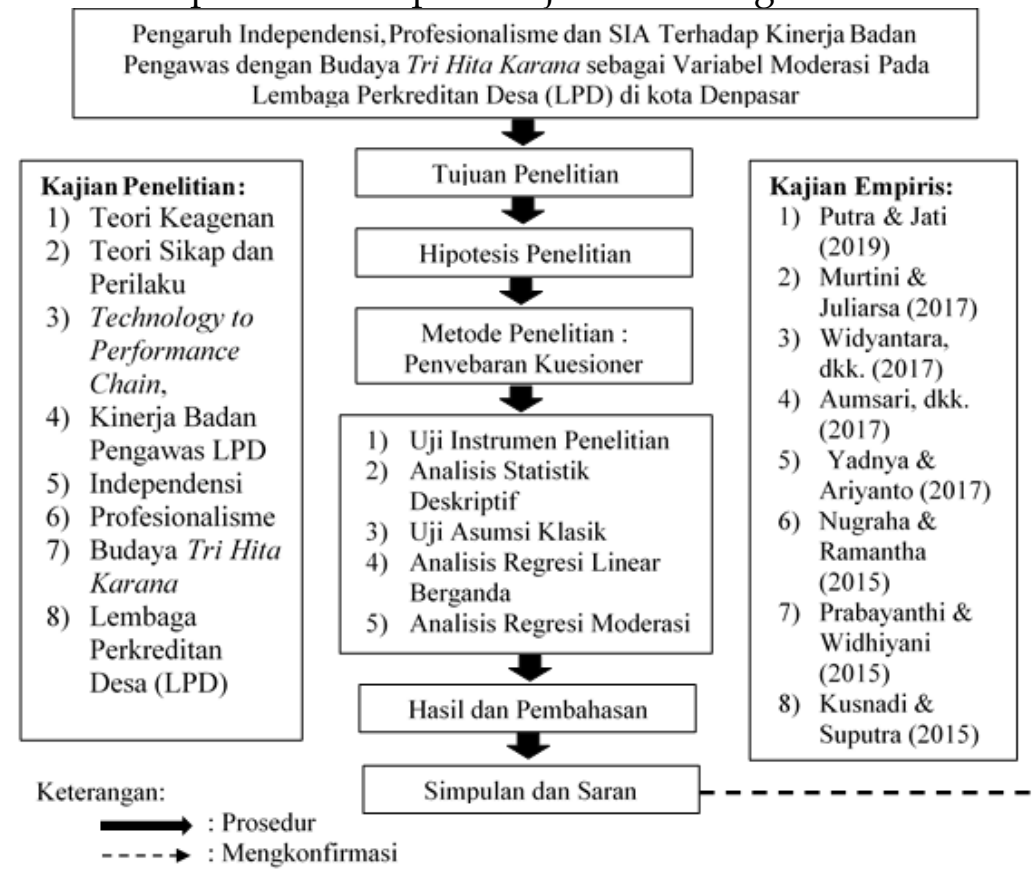

Gambar 2. Desain Penelitian

Sumber: Data Penelitian, 2020

Penelitian dilakukan pada 35 LPD di Kota Denpasar. Metode pengumpulan data yang digunakan dalam penelitian ini adalah dengan menggunakan kuesioner. Teknik analisis data yang digunakan dalam menguji hipotesis penelitian ini adalah regresi linear berganda. Dalam menggunakan teknik analisis linier berganda dan Uji Moderated Regression Analysis (MRA) merupakan aplikasi khusus mengenai interaksi perkalian dua atau lebih variabel independen (Naqvi, 2013). Adapun model regresi berganda dalam penelitian ini adalah sebagai berikut.

$Y=\alpha+\beta_{1} X_{1}+\beta_{2} X_{2}+\beta_{3} X_{3}+\varepsilon$

Keterangan:

Y : Kinerja pengawas LPD

$\mathrm{X}_{1} \quad$ : Independensi

$\mathrm{X}_{2} \quad$ : Profesionalisme

$X_{3}$ : Sistem pengendalian Internal

a : konstanta

$\beta 1-\beta 3:$ koefisien regresi

$\varepsilon \quad$ : error 
Adapun persamaan regresi yang dihasilkan dari model regresi moderasi daam penelitian ini adalah:

$Y=\alpha+\beta_{1} X_{1}+\beta_{2} X_{2}+\beta_{3} X_{3}+\beta_{3} Z+\beta_{4} X_{1} Z+\beta_{5} X_{2} Z+\beta_{3} X_{3} Z+\epsilon$

Keterangan:

$\mathrm{Y}=$ Efektivitas Penerapan Pengendalian Intern

a $=$ konstanta

$\mathrm{X}_{1}=$ Independensi

$\mathrm{X}_{2}=$ Profesionalisme

$\mathrm{X}_{3}=$ Sistem informasi akuntansi (SIA)

$\mathrm{Z}=$ Budaya Organisasi berbasis Tri Hita Karana

$\beta_{1}-\beta_{5}=\quad$ koefisien regresi

$\epsilon=$ standar error

Berdasarkan hasil analisis yang dilakukan dapat diamati mengenai statistik deskriptif, koefisien determinasi, uji kelayakan mod, dan uji hipotesis.

\section{HASIL DAN PEMBAHASAN}

Data penelitian diperoleh dari hasil kuesioner yang telah disebarkan kepada responden penelitian sejumlah 34 dewan pengawas LPD di Kota Denpasar. Karakteristik responden meliputi jenis kelamin, umur, tingkat pendidikan dan lama kerja responden. Pegawai LPD di Kota Denpasar dominan berjenis kelamin laki-laki dengan jumlah sebanyak 33 orang atau sebesar 97 persen, sedangkan pegawai perempuan sebanyak 1 orang atau 3 persen. Artinya lebih banyak pegawai laki-laki dibandingkan perempuan yang bekerja pada LPD di Kota Denpasar. Dilihat dari segi usia, responden yang berusia kurang dari 40 tahun sebanyak 1 orang atau sebesar 3 persen, responden yang berusia 41-50 tahun sebanyak 22 orang atau sebesar 65 persen, responden yang berusia 51-60 tahun sebanyak 7 orang atau 21 persen, responden yang berusia diatas 61 tahun sebanyak 4 orang atau 12 persen. Hal ini menunjukkan bahwa pegawai yang bekerja di LPD di Kota Denpasar mayoritas adalah yang berusia 41-50 tahun.

Mayoritas pegawai LPD di Kota Denpasar adalah kelompok responden dengan tingkat pendidikan Sarjana dengan jumlah sebanyak 25 orang atau 74 persen, kemudian responden dengan tingkat pendidikan SMA sebanyak 6 orang atau 18 persen, responden dengan tingkat pendidikan S2/ Pascasarjana sebanyak 2 orang atau 6 persen dan lainnya sebanyak 1 orang atau 3 persen. Informasi ini memberikan gambaran bahwa pegawai LPD di Kota Denpasar paling dominan adalah lulusan Sarjana yang dianggap sudah mampu serta memadai untuk menjadi pegawai LPD yang memiliki kompetensi untuk mencapai tujuan organisasi.

Pengelompokkan responden berdasarkan masa kerja menunjukkan bahwa responden yang bekerja pada LPD di Kota Denpasar dengan masa kerja selama kurang dari 5 tahun adalah sebanyak 6 orang atau 18 persen, kemudian responden yang bekerja selama 6 sampai 10 tahun sebanyak 6 orang atau 18 persen, sedangkan yang bekerja dari 11 sampai 15 tahun sebanyak 18 orang atau 53 persen, dan yang bekerja lebih dari 16 tahun sebanyak 4 orang atau 12 persen. Hal ini mengindikasikan bahwa sebagian besar pegawai LPD di Kota Denpasar memiliki masa kerja 11 sampai 15 tahun. 
Tabel 2. Hasil Uji Statistik Deskriptif

\begin{tabular}{lllllll}
\hline No & Variabel & N & Min & Max & Mean & Std. Dev \\
\hline 1 & Independensi $\left(\mathrm{X}_{1}\right)$ & 34 & 34 & 45 & 40,7059 & 3,81 \\
2 & Profesionalisme $\left(\mathrm{X}_{2}\right)$ & 34 & 24 & 35 & 31,2059 & 3,23 \\
3 & SIA $\left(\mathrm{X}_{3}\right)$ & 34 & 20 & 30 & 26,2059 & 3,02 \\
4 & Budaya Tri Hita Karana $(\mathrm{Z})$ & 34 & 43 & 60 & 53,6176 & 5,29 \\
5 & Kinerja pengawas LPD $(\mathrm{Y})$ & 34 & 44 & 60 & 53,2941 & 5,34 \\
\hline
\end{tabular}

Sumber: Data Penelitian, 2020

Berdasarkan Tabel 2, diperoleh nilai terendah dari jumlah skor jawaban responden untuk independensi sebesar 34 dan nilai tertinggi sebesar 45 . Nilai mean dari jumlah skor jawaban responden untuk variabel independensi 40,7059 berarti jika jumlah skor jawaban responden lebih besar dari 40,7059 maka termasuk responden yang memiliki independensi yang tinggi, dan sebaliknya. Nilai deviasi standar dari variabel independensi sebesar 3,81 hal ini menunjukkan bahwa sebaran data condong ke kanan namun masih dalam batas normal.

Variabel proesionalisme Nilai terendah dari jumlah skor jawaban responden sebesar 24 dan nilai tertinggi sebesar 35. Nilai mean dari jumlah skor jawaban responden sebesar 31,2059 berarti jika jumlah skor jawaban responden lebih besar dari 31,2059 maka termasuk responden menilai profesionalisme sangat baik, dan sebaliknya. Nilai standar deviasi dari variabel profesionalisme sebesar 3,23 hal ini menunjukkan bahwa sebaran data condong ke kanan tetapi masih dalam batas normal.

Variabel SIA nilai terendah dari jumlah skor jawaban responden untuk variabel SIA sebesar 20 dan nilai tertinggi sebesar 30. Nilai mean dari jumlah skor jawaban responden sebesar 26,2059 berarti jika jumlah skor jawaban responden lebih besar dari 26,2059 maka termasuk responden menilai SIA sangat baik, dan sebaliknya. Nilai standar deviasi dari variabel SIA sebesar 3,02 hal ini menunjukkan bahwa sebaran data condong ke kanan namun masih dalam batas normal.

Variabel budaya Tri Hita Karana nilai terendah dari jumlah skor jawaban responden sebesar 43 dan nilai tertinggi sebesar 60. Nilai mean dari jumlah skor jawaban responden sebesar 53,6176 berarti jika jumlah skor jawaban responden lebih besar dari 53,6176 maka termasuk responden memiliki Budaya Tri Hita Karana yang tinggi, dan sebaliknya. Nilai standar deviasi dari variabel Budaya Tri Hita Karana sebesar 5,29 hal ini menunjukkan bahwa sebaran data condong ke kanan namun masih dalam batas normal.

Variabel Kinerja pengawas LPD nilai terendah dari jumlah skor jawaban responden sebesar 44 dan nilai tertinggi sebesar 60 . Nilai mean dari jumlah skor jawaban responden sebesar 53.2941 berarti jika jumlah skor jawaban responden lebih besar dari 53,2941 maka termasuk responden memiliki kinerja pengawas LPD yang tinggi, dan sebaliknya. Nilai standar deviasi dari variabel kinerja pengawas LPD sebesar 5,34 hal ini menunjukkan bahwa sebaran data condong ke kanan namun masih dalam batas normal.

Berdasarkan hasil uji normalitas yang dilakukan menunjukkan bahwa nilai Asymp. Sig. (2-tailed) sebesar 0,100 lebih besar dari level of significant, yaitu sebesar 0,05 (5\%). Dari hasil analisis tersebut, maka dapat disimpulkan bahwa 
data berdistribusi normal. Berdasarkan hasil uji heteroskedasitas dapat dilihat bahwa nilai signifikansi masing-masing variable diatas $a=0.05$. Jadi dapat disimpulkan bahwa model MRA dari penelitian ini bebas dari gejala heterokedastisitas.

Hasil uji validitas untuk semua variabel yang diteliti menunjukan hasil valid. Variabel independensi menggunakan 9 pertanyaan memperoleh hasil valid dengan nilai $\mathrm{r}$ lebih besar dari 0,3 . Uji validitas variabel profesionalisme memperoleh nilai $\mathrm{r}$ hitung untuk item 1 adalah sebesar 0,739, item 2 adalah 0,586, item 3 adalah 0,672, item 4 adalah 0,842, item 5 adalah 0.680, item 6 adalah 0,480 , item 7 adalah 0,565. Hasil menunjukkan bahwa pertanyaan 1 sampai dengan 7 untuk variabel profesionalisme adalah valid karena niali $r$ lebih besar dari 0,3. Hasil Uji Validitas Variabel Sistem Informasi akuntansi (SIA) diketahui bahwa nilai $r$ hitung untuk item 1 adalah sebesar 0.533 , item 2 adalah 0.692, item 3 adalah 0.863 , item 4 adalah 0,721, item 5 adalah 0.841, item 6 adalah 0.767. Hasil menunjukkan bahwa pertanyaan 1 sampai dengan 6 untuk variabel SIA adalah valid karena niali $\mathrm{r}$ lebih besar dari 0.3. Hasil uji validitas variabel budaya organisasi berbsis Tri Hita Karana (Z), diketahui bahwa pertanyaan 1 sampai dengan 12 untuk variabel budaya organisasi berbasis Tri Hita Karana adalah valid karena niali r lebih besar dari 0.3.

Berdasarkan hasil uji reabilitas variabel independensi, profesionlisme, system informasi akuntansi dan kinerja pengawas LPD menunjukan bahwa output nilai $\mathrm{r}$ alpha untuk variabel independensi adalah sebesar 0,802 , variabel profesionalisme adalah 0,765 , variabel sistem adalah sebesar 0,819 dan variabel kinerja pengawas LPD adalah 0,895. Hasil menunjukkan bahwa variabel tersebut adalah reliabel karena nilai $\mathrm{r}$ alpha lebih besar dari 0.6.

Tabel 3. Hasil Analisis Moderasi Budaya Organisasi Berbasis Tri Hita Karana Terhadap Kinerja pengawas LPD

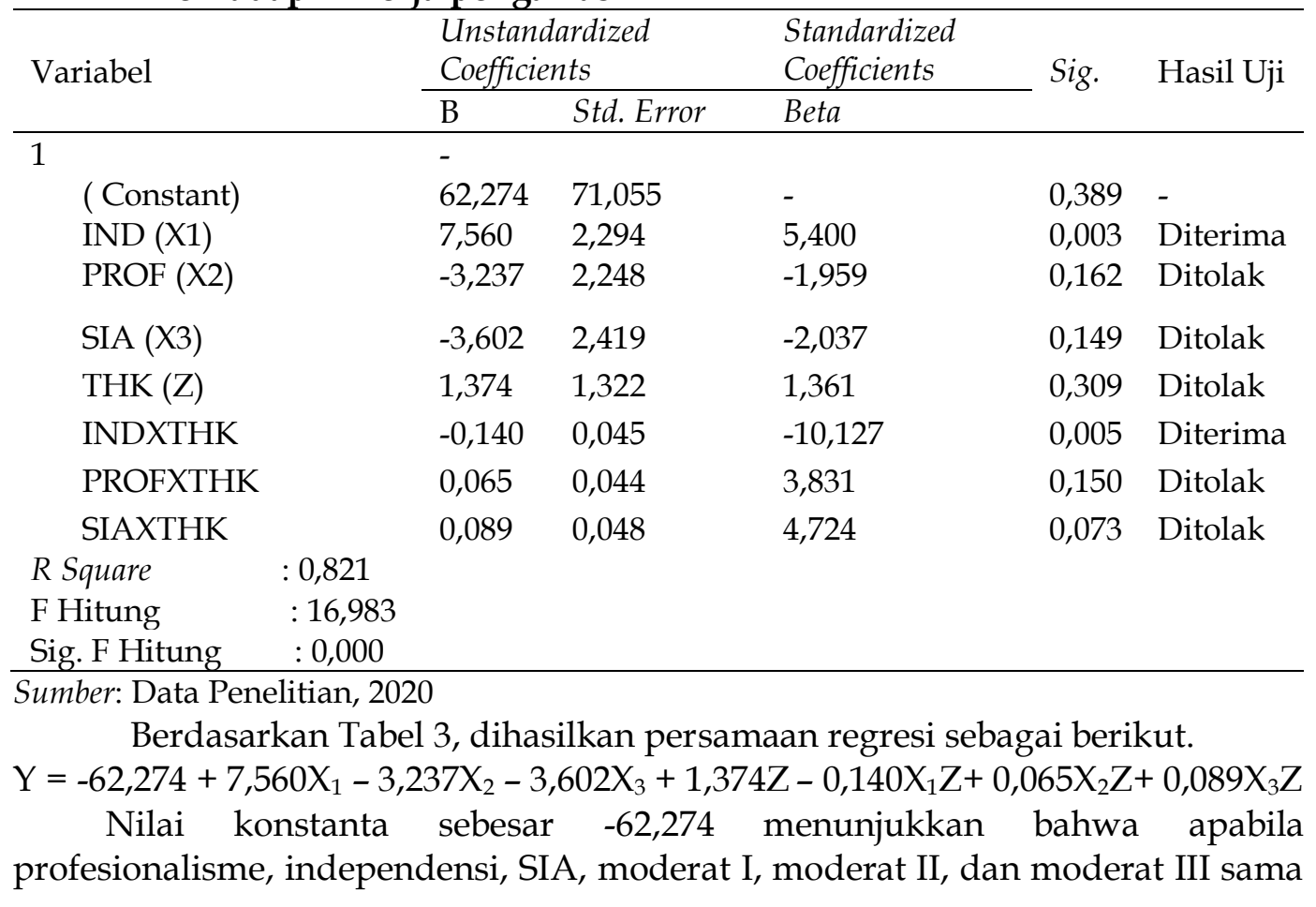


dengan nol, maka nilai kinerja pengawas LPD (Y) cenderung berkurang sebesar 62,274 .

Nilai koefisien $\beta_{1}$ pada variabel independensi sebesar 7,560 yang bernilai positif memiliki arti bahwa jika variabel lainnya konstan sementara independensi naik sebesar satu satuan, maka kinerja pengawas LPD akan meningkat sebesar 7,560 satuan. Nilai koefisien $\beta_{2}$ pada variabel profesionalisme sebesar -3,237 yang bernilai negatif memiliki arti bahwa jika variabel lainnya konstan sementara profesionalisme naik sebesar satu satuan, maka kinerja pengawas LPD akan menurun sebesar 3,237 satuan. Nilai koefisien $\beta_{3}$ pada variabel SIA sebesar -3,602 yang bernilai negatif memiliki arti bahwa apabila variabel lainnya konstan sementara variabel SIA naik sebesar satu satuan maka kinerja pengawas LPD akan menurun sebesar 3,602 satuan. Nilai koefisien $\beta_{4}$ pada variabel budaya organisasi berbasis Tri Hita Karana sebesar 1,374 yang bernilai positif memiliki arti bahwa variabel lainnya konstan sementara variabel budaya organisasi berbasis Tri Hita Karana naik sebesar satu satuan maka kinerja pengawas LPD akan meningkat sebesar 1,374 satuan. Nilai koefisien $\beta_{5}$ pada variabel moderat I $\left(X_{1} Z\right)$ karena sebesar $-0,140$ yang bernilai negatif memiliki arti bahwa variabel lainnya konstan sementara variabel moderat I naik sebesar satu satuan maka kinerja pengawas LPD menurun sebesar 0,140 satuan. Nilai $\beta_{6}$ pada variabel moderat II $\left(\mathrm{X}_{2} \mathrm{Z}\right)$ karena sebesar 0,065 yang bernilai positif memiliki arti bahwa variabel lainnya konstan sementara variabel moderat II meningkat sebesar satu satuan maka variabel kineja badan pengawas LPD meningkat sebesar 0,065 satuan. Nilai $\beta_{7}$ pada variabel moderat III $\left(X_{3} Z\right)$ sebesar 0,089 yang bernilai positif memiliki arti bahwa variabel lainnya konstan sementara variabel moderat III meningkat sebesar satu satuan maka variabel kinerja pengawas LPD meningkat sebesar 0,089 satuan.

Analisis koefisien determinasi dilakukan guna mengukur seberapa besar variabel bebas mampu menjelaskan perubahan variabel terikatnya. Berdasarkan Tabel 3, dapat dilihat bahwa nilai $R$ Square pada model sebesar 0,821 atau 82.1 persen, ini berarti bahwa sebesar 82,1 persen variasi kinerja pengawas LPD dipengaruhi oleh variabel independensi, profesionalisme, SIA, dan budaya berbasis Tri Hita Karana, sedangkan 17,9 persen dipengaruhi oleh variabel lain diluar model penelitian.

Uji kelayakan model (uji F) memiliki tujuan untuk menguji apakah semua variabel bebas berpengaruh terhadap variabel terikat dan untuk mengetahui MRA yang digunakan dalam penelitian ini layak diuji atau tidak. Berdasarkan Tabel 3, Hasil perhitungan MRA menunjukkan bahwa nilai $p$-value sebesar 0.000 yang lebih kecil dari nilai $a=0.05$ hal ini menunjukkan bahwa seluruh variabel independen mampu memprediksi atau menjelaskan kinerja pengawas LPD dan menunjukkan bahwa model yang digunakan pada penelitian ini adalah layak untuk diteliti.

Berdasarkan perhitungan dengan MRA diperoleh nilai probabilitas independensi terhadap kinerja pengawas LPD sebesar 0,003. Dengan demikian maka 0,003 < 0,05 dapat disimpulkan bahwa independensi berpengaruh terhadap kinerja pengawas LPD. Dengan koefisien sebesar 7,560 maka hipotesis pertama diterima. Nilai probabilitas profesionalisme terhadap kinerja pengawas LPD sebesar 0,162. Dengan demikian maka 0,162 >0,05 dapat disimpulkan 
bahwa profesionalisme tidak berpengaruh terhadap kinerja pengawas LPD. Dengan koefisien sebesar -3,237 maka hipotesis kedua ditolak. Nilai probabilitas SIA terhadap kinerja pengawas LPD sebesar 0,149. Dengan demikian maka 0,149 $>0,05$ dapat disimpulkan bahwa SIA tidak berpengaruh terhadap kinerja pengawas LPD. Dengan koefisien sebesar -3,602 maka hipotesis ketiga ditolak. Berdasarkan perhitungan dengan MRA diperoleh nilai probabilitas variabel moderat I $\left(X_{1} Z\right)$ terhadap kinerja pengawas LPD sebesar 0.005. Dengan demikian maka 0,005 < 0,05 dapat disimpulkan bahwa moderat I berpengaruh terhadap kinerja pengawas LPD. Hal ini menunjukkan bahwa budaya organisasi berbasis Tri Hita Karana memoderasi independensi terhadap kinerja pengawas LPD. Dengan koefisien sebesar -0,140 maka hipotesis keempat diterima.

Berdasarkan perhitungan dengan MRA diperoleh nilai probabilitas moderasi II $\left(\mathrm{X}_{2} \mathrm{Z}\right)$ terhadap kinerja pengawas LPD sebesar 0,150. Dengan demikian maka 0,150 > 0,05 dapat disimpulkan bahwa moderat II tidak berpengaruh terhadap kinerja pengawas LPD. Dengan koefisien sebesar 0,065 maka hipotesis kelima ditolak. Hal ini menunjukkan bahwa budaya Tri Hita Karana tidak memoderasi profesionalisme terhadap kinerja pengawas LPD. Berdasarkan perhitungan dengan MRA diperoleh nilai probabilitas moderat III $\left(\mathrm{X}_{3} \mathrm{Z}\right)$ terhadap kinerja pengawas LPD sebesar 0,073. Dengan demikian maka $0,073>0,05$ dapat disimpulkan bahwa moderat III tidak berpengaruh terhadap kinerja pengawas LPD. Dengan koefisien sebesar 0,089 maka hipotesis keenam ditolak. Hal ini menunjukkan bahwa budaya organisasi berbasis Tri Hita Karana tidak memoderasi SIA terhadap kinerja pengawas LPD.

Hipotesis satu menyatakan bahwa independensi berpengaruh positif terhadap kinerja badan pengawas LPD. Hasil uji statistik menunjukkan bahwa hipotesis pertama $\left(\mathrm{H}_{1}\right)$ diterima. Menurut Putra \& Jati (2019) mengemukakan bahwa badan pengawas LPD harus memiliki sikap integritas dan objektivitas dalam melaksanakan tugas profesionalnya dan setiap badan pengawas LPD harus bersikap independen dari semua kepentingan yang akan mempengaruhinya. Penelitian ini sesuai dengan teori sikap dan perilaku (theory of attitude and behavior) yaitu seorang badan pengawas LPD dapat mengelola sikap atau faktor personalnya sehingga mampu bertindak jujur, tidak memihak pada suatu kepentingan tertentu, dan berpikir rasional dalam mengambil suatu keputusan sehingga badan pengawas LPD dapat menjalankan kinerjanya dengan maksimal dan sesuai dengan apa yang direncanakan. Hasil penelitian ini sejalan dengan penelitian yang dilakukan oleh Putra \& Jati (2019) yang menyatakan bahwa independensi berpengaruh positif dan signifikan terhadap kinerja badan pengawas LPD sebagai auditor internal LPD. Begitu pula dengan penelitian Murtini \& Juliarsa (2017) serta Widyantara et al., (2017) yang dalam penelitiannya menunjukkan independensi berpengaruh positif dan signifikan terhadap kinerja badan pengawas. Arumsari, et al., (2014) serta Yadnya \& Ariyanto (2017) juga mendukung yaitu dalam penelitiannya menyatakan independensi terbukti memberikan pengaruh positif dan signifikan terhadap kinerja internal auditor.

Yadnya \& Ariyanto (2017) menyatakan bahwa sikap independensi auditor merupakan suatu sikap kejujuran seorang auditor untuk dapat menyelesaikan tugas-tugasnya dengan kesungguhan hati agar menghasilkan kinerja yang maksimal dan tinggi. Tingginya independensi yang dimiliki oleh 
seorang auditor maka akan diikuti pula dengan tingginya kinerja dari auditor tersebut. Menurut Putra \& Jati (2019) sikap independensi dari badan pengawas LPD ditunjukkan dengan badan pengawas tidak boleh merangkap menjadi pengurus LPD. Badan pengawas LPD diharapkan mampu memberikan bukti dan juga mengemukakan pendapatnya sesuai dengan fakta-fakta yang diperoleh selama menjalankan kegiatan pengawasan dan pemeriksaan. Meningkatnya keandalan hasil pengawasan dan sikap independensi dari badan pengawas LPD nantinya juga akan meningkatkan kinerja dari badan pengawas LPD itu sendiri. Profesionalisme berpengaruh positif terhadap kinerja badan pengawas LPD adalah penyataan hipotesis 2 . Berdasarkan hasil uji statistik menunjukkan bahwa hipotesis kedua $\left(\mathrm{H}_{2}\right)$ ditolak, yang artinya profesionalisme tidak berpengaruh terhadap kinerja badan pengawas LPD. Hasil dari penelitian ini tidak sejalan dengan teori sikap dan perilaku (Theory of Attitude and Behavior), dimana setiap badan pengawas LPD harus memiliki sikap keahlian profesional serta ketelitian dan mampu mengatasi masalah meski dalam keadaan tertekan yang nantinya akan mempengaruhi bagaimana kinerja dari badan pengawas tersebut. Hasil penelitian ini tidak sejalan dengan hasil penelitian yang dilakukan oleh Murtini \& Juliarsa (2017) yang membuktikan bahwa profesionalisme berpengaruh positif terhadap kinerja badan pengawas sebagai fungsi auditor internal dalam sistem pengendalian internal. Begitu pula dengan penelitian yang dilakukan oleh Putra \& Jati (2019) membuktikan bahwa profesionalisme berpengaruh positif dan signifikan terhadap kinerja badan pengawas LPD. Penelitian Prabayanthi \& Widhiyani (2018) serta Nugraha \& Ramantha, (2015) juga memperoleh hasil profesionalisme memberikan pengaruh positif terhadap kinerja auditor internal.

Menurut Nugraha \& Ramantha (2015) profesionalisme adalah sikap seseorang yang menjalani profesi sesuai dengan keahlian yang dimilikinya. Seorang profesional dipercaya dan dapat diandalkan dalam melaksanakan pekerjaannya sehingga dapat berjalan lancar, baik, dan mendatangkan hasil yang diharapkan. Seorang badan pengawas yang memiliki keahlian profesional akan dapat cepat dan tanggap dalam mendeteksi kesalahan maupun kekeliruan yang mungkin dapat terjadi dalam melaksanakan pengawasan dan pemeriksaan kegiatan operasional LPD. Hasil ini kemungkinan karena pengawasan LPD dipilih oleh masyarakat tanpa memperhatikan faktor profesionalisme tetapi lebih memperhatikan unsur kepercayaan dan unsur rasa penghargaan.

Hipotesis ketiga $\left(\mathrm{H}_{3}\right)$ dalam penelitian ini adalah sistem informasi akuntansi berpengaruh positif kinerja dewan pengawas LPD di kota Denpasar. Berdasarkan hasil uji statistik yang dilakukan menunjukan hasil bahwa SIA tidak berpengaruh pada kinerja dewan pengawas di LPD kota Denpasar. Hasil penelitian tidak sejalan dengan penelitian yang dilakukan oleh Kasandra \& Juliarsa (2016), Murni \& Juliarsa (2018), Rizaldi (2015), Astuti \& Darmadiaksa (2014), Pratami \& Damayanthi (2018) dan Listiana (2017) menyatakan bahwa sistem informasi akuntansi mempengaruhi kinerja karyawan. Hal ini menunjukan bahwa sistem informasi akuntansi merupakan salah satu faktor penting dalam menciptakan kinerja karyawan. Karena sistem informasi akuntansi mempunyai pengaruh langsung terhadap karyawan di dalam menyelesaikan pekerjaannya yang pada akhirnya akan meningkatkan kinerja organisasi. Hasil penelitian ini memberikan bukti dalam melakukan pengawasan 
masih dilakukan secara manual dan konvesional. Kemungkinan SIA yang ada di LPD belum maksimal digunakan sehingga SIA tidak terlalu diperlukan. Hasil ini tidak mendukung pernyataan bahwa sistem informasi akuntansi (SIA) berguna untuk membantu para karyawan dalam suatu perusahaan untuk ngambil keputusan yang bermanfaat, hal ini sejalan dengan Technology to Performance Chain yang menyatakan bahwa sebuah teknologi akan sangat berdampak pada kinerja. Serta sejalan dengan Theory of Attitude and Behavior yang menyatakan bahwa perilaku menentukan bagaimana seseorang menggunakan alat kerjanya, dengan terbiasa menggunakan sistem informasi akuntansi dalam bekerja akan memudahkan karyawan dalam bekerja, sehingga produktivitas meningkat dan kinerja yang dihasilkan juga akan meningkat.

Berdasarkan hasil uji MRA yang menguji hipotesis pemoderasi menunjukan variabel budaya Tri Hita Karana mampu memoderasi pengaruh independensi terhadap kinerja badan pengawas LPD dan hipotesis keempat $\left(\mathrm{H}_{4}\right)$ tersebut diterima. Hasil positif dari koefisien moderat menunjukkan bahwa variabel budaya Tri Hita Karana mampu memoderasi secara positif atau memperkuat pengaruh indepedensi terhadap kinerja badan pengawas LPD secara signifikan.

Hasil penelitian ini mendukung hasil penelitian dari Sudiartini \& Mimba (2018) menyatakan bahwa budaya organisasi berbasis Tri Hita Karana berpengaruh positif pada kinerja badan pengawas LPD. Hal tersebut menunjukkan bahwa semakin kuat dan tinggi budaya organisasi berbasis Tri Hita Karana yang diterapkan, maka akan meningkatkan kinerja dari badan pengawas LPD. Sejalan dengan hal tersebut, budaya Tri Hita Karana dapat memoderasi karena menurut Mustikayani \& Dwirandra (2016) budaya Tri Hita Karana ini dijadikan modal utama prinsip hidup seseorang sebagai suatu individu yang memandang diri dan lingkungannya sebagai suatu sistem yang dikendalian oleh nilai keseimbangan, dan diwujudkan dalam bentuk perilaku dengan mengimplementasikan budaya Tri Hita Karana ini.

Hasil pengujian ini menunjukkan bahwa peran moderasi dari variabel budaya Tri Hita Karana pada variabel independensi adalah bersifat memperkuat, artinya sikap independensi yang semakin baik dengan diikuti oleh penerapan budaya Tri Hita Karana akan dapat meningkatkan kinerja dari badan pengawas LPD secara bersama-sama. Menurut Sudiartini \& Mimba (2018) kesesuaian budaya Tri Hita Karana yang diterapkan LPD dengan perilaku badan pengawas LPD memiliki kemampuan untuk meningkatkan kinerjanya karena penerapan budaya Tri Hita Karana dalam LPD mampu memotivasi badan pengawas untuk dapat bekerja lebih baik sehingga dapat meningkatkan kinerjanya. Selain itu, menurut Adiputra, et.al. (2014) ketiga bagian dari budaya Tri Hita Karana yaitu parahyangan, pawongan, dan palemahan menjadi dasar dalam pengambilan keputusan dan memberikan suatu pandangan kepada badan pengawas LPD. Pegangan yang kuat akan nilai-nilai yang terkandung dalam budaya Tri Hita Karana ini bagi setiap badan pengawas LPD ternyata dapat memberikan dukungan terhadap pola pikir dari setiap badan pengawas LPD untuk senantiasa bertindak jujur, tidak memihak pada suatu kepentingan apapun, serta berintegritas tinggi. Sehingga pada kenyataannya budaya Tri Hita Karana dapat 
meningkatkan sikap independensi dan menghasilkan kinerja badan pengawas LPD yang lebih baik dan mengalami peningkatan.

Hasil pengujian hipotesis variabel budaya Tri Hita Karana tidak mampu memoderasi pengaruh profesionalisme terhadap kinerja badan pengawas LPD. Hipotesis kelima $\left(\mathrm{H}_{5}\right)$ dalam penelitian ini ditolak, artinya variabel budaya Tri Hita Karana tidak mampu memoderasi pengaruh profesionalisme terhadap kinerja badan pengawas LPD. Hasil pengujian ini menunjukkan bahwa peran moderasi dari variabel budaya Tri Hita Karana pada variabel independensi adalah bersifat memperkuat, artinya sikap independensi yang semakin baik dengan diikuti oleh penerapan budaya Tri Hita Karana akan dapat meningkatkan kinerja dari badan pengawas LPD secara bersama-sama. Hasil penelitian ini mendukung penelitian yang dilakukan oleh Winarsih \& Suardana (2018) yang menyatakan bahwa budaya organisasi berpengaruh negatif terhadap kinerja pengawas LPD. Hal tersebut menunjukkan bahwa semakin tinggi budaya organisasi maka kinerja pengawas semakin menurun. Sejalan dengan hal tersebut, fenomena yang ditunjukkan oleh penelitian ini membuktikan bahwa penerapan budaya Tri Hita Karana tidak mampu meningkatkan sikap profesionalisme yang dimiliki oleh badan pengawas LPD. Menurut Bhuwaneswari \& Damayanthi (2018) sikap profesionalisme atau keahlian profesional didapatkan dari pelatihan dan pengalaman, sehingga lingkungan atau budaya organisasi sekitar tidak dapat mempengaruhi tingkat profesionalisme badan pengawas LPD. Pelatihan yang diikuti oleh badan pengawas LPD akan berdampak pada meningkatnya sikap profesionalisme yang mereka miliki dan pada akhirnya akan mempengaruhi kinerja dari badan pengawas LPD itu sendiri.

Hasil pengujian hipotesis variabel budaya Tri Hita Karana tidak mampu memoderasi pengaruh SIA terhadap kinerja badan pengawas LPD. Hipotesis keenam $\left(\mathrm{H}_{6}\right)$ dalam penelitian ini ditolak, artinya variabel budaya Tri Hita Karana tidak mampu memoderasi pengaruh SIA terhadap kinerja badan pengawas LPD. Hasil pengujian ini menunjukkan bahwa peran moderasi dari variabel budaya Tri Hita Karana pada variabel SIA adalah tidak terbukti. Lembaga Perkreditan Desa (LPD) merupakan lembaga keuangan non bank yang dimiliki oleh komunitas adat dengan sistem ekonomi berbanjaran khas Bali (Suartana, 2013). LPD dikelola berdasarkan falsafah Tri Hita Karana yang sangat kuat dengan budaya Hindu yang menjadi pilar utama pendukung kebudayaan. Kalau memperhatikan badan pengawas di LPD pengawasan LPD belum sepenuhnya menggunakan SIA. Sehingga budaya tidak dapat memperkuat pengaruh SIA terhadap kinerja. Hasil penelitian ini tidak sejalan dengan hasil penelitian yang dilakukan oleh Pratami \& Damayanthi (2018) serta Murni \& Juliarsa (2018) menyatakan bahwa penyampaian sistem informasi akuntansi melalui budaya organisasi berpengaruh terhadap kinerja karyawan. Theory of Attitude and Behavior menyatakan bahwa perilaku seseorang akan dipengaruhi oleh kebiasaan yang terkait dengan apa yang mereka biasa lakukan, sehingga penyampaian pengendalian internal melalui budaya organisasi akan lebih mudah diterima oleh karwayan dan akan mempengaruhi kinerja dari karyawan tersebut juga tidak terbukti pada penelitian ini. 


\section{SIMPULAN}

Simpulan yang dapat diberikan independensi berpengaruh positif terhadap kinerja badan pengawas LPD di Kota Denpasar. Hasil ini menjelaskan bahwa semakin independen seorang badan pengawas LPD maka akan semakin meningkatkan kinerja badan pengawas LPD dalam melaksanakan pengawasan. Profesionalisme tidak berpengaruh kinerja badan pengawas LPD di Kota Denpasar. Hasil ini berarti bahwa profesional seorang badan pengawas LPD sebenarnya sangat diperlukan tetapi kemungkin di LPD lebih kepada asas kepercayaan masyakat pada dewan pengawas. SIA tidak berpengaruh terhadap kinerja badan pengawas LPD di kota Denpasar. Hasil SIA tidak mempengaruhi kinerja badang pengawas LPD. Karena pengawasan yang dilakukan pada LPD masih bersifat manual dan konvensional sehingga kemungkinan tidak banyak pengaruh penggunaan SIA. Budaya Tri Hita Karana mampu memoderasi dan memperkuat pengaruh independensi terhadap kinerja badan pengawas LPD di Kota Denpasar. Hasil ini menjelaskan bahwa sikap independensi yang semakin baik dengan diikuti oleh penerapan budaya Tri Hita Karana akan dapat meningkatkan kinerja dari badan pengawas LPD. Budaya Tri Hita Karana tidak mampu memoderasi pengaruh profesionalisme terhadap kinerja badan pengawas LPD di Kota Denapsar. Hasil ini berarti bahwa sikap profesionalisme yang diikuti oleh penerapan budaya Tri Hita Karana tidak memberikan pengaruh pada peningkatan kinerja dari badan pengawas LPD. Budaya Tri Hita Karana tidak mampu memoderasi pengaruh SIA terhadap kinerja badan pengawas LPD di Kota Denpasar. Hasil ini berarti bahwa SIA yang diikuti oleh penerapan budaya Tri Hita Karana tidak memberikan pengaruh pada peningkatan kinerja dari badan pengawas LPD.

Adapun saran yang peneliti dapat berikan dari hasil penelitian ini adalah diharapkan agar setiap LPD dapat memilih anggota badan pengawas internal yang memiliki keahlian profesional atau pengalaman di bidang pengawasan maupun audit. LPD sebaiknya juga mempertimbangkan menggunaan SIA pada kegitan di LPD. Selain itu setiap anggota badan pengawas harus memiliki pengalaman yang cukup dalam melaksanakan pengawasan agar nantinya dapat menghasilkan kinerja operasional LPD yang lebih baik kedepannya. Setiap LPD juga harus dapat memberikan fasilitas kepada para pengawas internal dalam mengikuti pendidikan profesional berkelanjutan agar dapat lebih meningkatkan keahlian profesional yang dimilik oleh badan pengawas LPD. Selain itu, untuk meningkatkan sikap independensi badan pengawas LPD, masyarakat desa adat dan pengurus LPD dapat memilih anggota badan pengawas yang tidak memiliki hubungan (keluarga) dengan pimpinan LPD sehingga nantinya setiap pengawas internal LPD dapat bertugas tanpa diikuti oleh kecurangan maupun bekerja berdasarkan kepentingan pribadi.

\section{REFERENSI}

Adiputra, I Made Pradana; Atmadja, Anantawikrama Tungga; Saputra, K. A. K. (2014). Culture of Tri Hita Karana as Moderating Effect of Locus of Control on the Performance of Internal Auditor (Studies in the Office of the Provincial Inspectorate in Bali). Research Journal of Finance and Accounting, 5(22), 27-36. 
Akmal. (2006). Pemeriksaan Intern (Intern Audit) Edisi Bahasa Indonesia. PT. Indeks Kelompok Gramedia.

Al-Eqab, M., \& Adel, D. (2013). The Impact of IT Sophistications on the Perceived Usefulness of Accounting Information Characteristics among Jordanian Listed Companies Mahmoud Al-Eqab College of Bussiness Adminstration Prince Sultan University Riyadh, Kingdome of Saudi Arabia College o. International Journal of Business and Social Science, 4(3), 145-155.

Arsiningsih, N. L. P. F., Diatmika, P. G., \& Darmawan, N. A. S. (2015). Pengaruh Penggunaan Teknologi Informasi, Efektivitas Sistem Informasi Akutansi, Sistem Pengendalian Intern terhadap Kinerja Karyawan pada Bank Perkreditan Rakyat di Kabupaten Buleleng dan Bangli. E-Journal S1 Ak Universitas Pendidikan Ganesha, 3(1).

Arumsari, Lukyta Adelia; Budhiarta, I. K. (2014). Pengaruh Profesionalisme Auditor, Independensi Auditor, Etika Profesi, Budaya Organisasi, dan Gaya Kepemimpinan terhadap Kinerja Auditor pada Kantor Akuntan Publik di Bali. E-Jurnal Akuntansi, 5(8), 2297-2304.

Astuti, N. M. M. P., \& Dharmadiaksa, I. B. (2014). Pengaruh Efektivitas Penerapan Sistem Informasi Akuntansi, Pemanfaatan dan Kesesuaian Tugas pada Kinerja Karyawan. E-Journal Akuntansi, 9(2), 373-384.

Bhuwaneswari, A. A. A. Mas; Damayanthi, I. G. A. E. (2018). Pengaruh Karakteristik Pengawas Internal terhadap Efektivitas Pengendalian Internal Lembaga Perkreditan Desa di Kota Denpasar Anak. E-Jurnal Akuntansi, 22(3), 1800-1825.

Fuad, H., \& Trisnawati, R. (2015). Pengaruh Pengalaman, Otonomi, Profesionalisme, Ambiguitas Peran, dan Motivasi terhadap Kinerja Auditor (Studi Empiris pada Kantor Akuntan Publik di Surakarta dan Semarang). Naskah Publikasi Fakultas Ekonomi Dan Bisnis Universitas Muhammadiyah Surakarta, 3(1), 1-11.

Futri, P. S., \& Juliarsa, G. (2014). Pengaruh Independensi, Profesionalisme, Tingkat Pendidikan, Etika Profesi, Pengalaman, Dan Kepuasan Kerja Auditor Pada Kualitas Audit Kantor Akuntan Publik Di Bali. E-Jurnal Akuntansi, 7(2), 444-461.

Goodhue, D. L., \& Thompsom, R. L. (1995). Task-Technology Fit and Individual Performance. MIS Quantenly, 19(2), 213.

Grande, E. U., Estebanez, R. P., \& Colomina, C. M. (2011). The impact of Accounting Information Systems ( AIS ) on performance measures: empirical evidence in Spanish SMEs 1. The International Journal of Digital Accounting Research, 11(June 2010), 25-43. https://doi.org/10.4192/15778517-v11

Gunawan, I. M. A. P., \& Tenaya, A. I. (2017). Pengaruh Efektivitas Sistem Informasi Akuntansi pada Kinerja Individual dengan Kemampuan Teknik Personal sebagai Pemoderas. E-Journal Akuntansi, 20, 1621-1647.

Gupta, M. P., Kanungo, S., Kumar, R., \& Sahu, G. P. (2007). A Study of Information Technology Effectiveness in Select Government Organizations in India. Juornal for Desicion Markets, 32(2), 7-21.

Kasandra, N. M. A. A., \& Juliarsa, G. (2016). Pengaruh Kualitas Penerapan SIA, Pemanfaatan dan Kepercayaan Teknologi Informasi pada Kinerja 
Karyawan. E-Journal Akuntansi Universitas Udayana, 14(1), 539-547.

Kusnadi, I. M. G., \& Suputra, D. G. D. (2015). Pengaruh Profesionalisme Dan Locus of Control Terhadap Kinerja Auditor Di Kantor Akuntan Publik Provinsi Bali. E-Jurnal Akuntansi, 13(1), 276-291.

Listiana, I. (2017). Pengaruh Sistem Informasi Akuntansi dan Sistem Pengendalian Internal terhadap Kinerja Karyawan (Studi Kasus pada KSPPS Bina Insan Mandiri). Skripsi Fakultas Ekonomi Dan Bisnis Islam, Institut Agama Islam Negeri Surakarta.

Lubis, A. I. (2009). Akuntansi Keprilakuan. Salemba Empat.

Mercury, G. A., \& Putri, I. G. A. M. A. D. (2015). Pengaruh Partisipasi Penganggaran dan Informasi Asimetri Pada Senjangan Anggaran dengan Budaya Organisasi sebagai Variabel Moderasi. E-Jurnal Akuntansi, 13(3), 1070-1099.

Mulyawan, I Putu; Wirama, Dewa Gede; Badera, I. D. N. (2017). Budaya Tri Hita Karana Sebagai Pemoderasi Pengaruh Prinsip Good Corporate Governance pada Kinerja Lembaga Perkreditan Desa di Kota Denpasar. E-Jurnal Ekonomi Dan Bisnis, 8, 3193-3222.

Murni, N. N. N. S., \& Juliarsa, G. (2018). Pengaruh Efektivitas Sistem Informasi Akuntansi pad Kinerja Karyawan dengan Budaya Organisasi sebagai Variabel Mediasi. E-Jurnal Akuntansi, 24(1), 715-740.

Murtini, N. N., \& Juliarsa, G. (2017). Pengaruh Independensi, Keahlian Profesional, Pengalaman Kerja, dan Tingkat Pendidikan Pada Kinerja Pengawas Koperasi. E-Jurnal Akuntansi, 20(2), 1390-1418.

Mustikayani, N. L. P. D., \& Dwirandra, A. A. N. B. (2016). Budaya Tri Hita Karana Sebagai Pemoderasi Kompleksitas Tugas dan Tekanan Waktu Terhadap Kinerja Auditor. E-Jurnal Akuntansi, 16(2), 1544-1573.

Nugraha, I. S. A., \& Ramantha, I. W. (2015). Pengaruh Profesionalisme, Etika Profesi dan Pelatihan Auditor Terhadap Kinerja Auditor Pada Kantor Akuntan Publik di Bali. E-Jurnal Akuntansi, 13(3), 916-943.

Prabayanthi, P. A., \& Widhiyani, N. L. S. (2018). Profesionalisme, Budaya Organisasi dan Komitmen Organisasi pada Kinerja Auditor. E-Jurnal Akuntansi, 22(2), 1059-1084.

Pratama, G. A. P., \& Suardikha, I. M. S. (2013). Keahlian Pemakai dan Kenyamanan Fisik Tingkat Efektivitas Sistem Informasi Akuntansi terhadap Kinerja Karyawan. E-Journal Akuntansi, 2, 361-381.

Pratami, L. A. R., \& Damayanthi, I. G. A. E. (2018). Budaya Organisasi Memediasi Kualitas Penerapan Sistem Informasi Akuntansi dan Kepercayaan Teknologi Informasi Pada Kinerja Karyawan. EJurnal Akuntansi, 22(2), 10321058.

Putra, I. G. A. D., \& Wisadha, I. G. S. (2012). Pengaruh Profesionalisme, Independensi, dan Pengalaman Auditor Pada Kualitas Audit Badan Pengawas Lembaga Perkreditan Desa LPD). E-Jurnal Akuntansi, 89-98.

Putra, I. G. A., \& Jati, I. K. (2019). Analisis Pengaruh Profesionalisme, Independensi dan Pengalaman Kerja Pada Kinerja Pengawas Internal (Panureksa) LPD. E-Jurnal Akuntansi, 26, 1464.

Safitri, D. (2014). Pengaruh Independensi Auditor dan Gaya Kepemimpinan Terhadap Kinerja Auditor Dengan Komitmen Organisasi Sebagai Variabel 
Intervening (Studi Empiris : Kantor Akuntan Publik Pekanbaru, Batam, dan Medan). Jurnal Ilmiah Akuntansi Dan Bisnis, 11(2), 339-351.

Salju, Rismawati, \& Bachtiar, M. D. (2014). Pengaruh Kompetensi dan Independensi Terhadap Kinerja Auditor Pemerintah Kabupaten Luwu Timur. Jurnal Equilibrium, 04(02), 100-123.

Samuel, N. (2013). Impact of Accounting Information Systems on Organizational Effectiveness of Automobile Companies in Kenya. Journal Universitas Of Nairobi, November.

Saraswati, N. L. M. G. P., \& Damayanthi, I. G. A. E. (2018). Pengaruh Kualitas Sistem Informasi Akuntansi, Norma Su. E-Journal Akuntansi, 25(2), 13391368.

Soudani, S. N. (2012). The Usefulness of an Accounting Information System for Effective Organizational Performance. Internasional Journal of Economics and Finance, 4(5), 136-145. https:/ / doi.org/10.5539/ijef.v4n5p136

Suartana, I. W. (2009). Arsitektur Pengelolaan Risiko pada Lembaga Perkreditan Desa (LPD). Udayana University Press.

Sudiartini, N. L. Y., \& Mimba, N. P. S. H. (2018). Pengaruh Locus of Control dan Budaya Organisasi berbasis Tri Hita Karana pada Kinerja Badan Pengawas. E-Jurnal Akuntansi, 22, 381.

Surya, I. B. K., Armanu, T., Achmad, F., \& Mintarti, R. (2014). Tri Hita Karana Effect on Company Performance, Leadership and Organizational Commitment (Studies an Regional Water Company in Bali Province). International Journal of Business and Management Invention, 3(6), 13-26.

Swari, I. A. P. Candra Mitha; Ramantha, I. W. (2013). Pengaruh Independensi Dan Tiga Kecerdasan Terhadap Pertimbangan Pemberian Opini Auditor. EJurnal Akuntansi, 4(3), 489-508.

Widyantara, I. N., Wahyuni, M. A., \& Atmadja, A. T. (2017). Pengaruh Independensi, Motivasi, Kompetensi, dan Pengalaman Kerja Terhadap Kinerja Badan Pengawas Sebagai Auditor Internal Pada Lembaga Perkreditan Desa (LPD) di Kecamatan Buleleng. E-Journal S1 Ak Universitas Pendidikan Ganesha, 8(2).

Wijaya, O. (2018). Pengaruh Profesionalisme, Independensi, Budaya Organisasi, Motivasi, Serta Gaya Kepemimpinan Terhadap Kinerja Auditor (Studi Empiris Pada Kantor Inspektorat Pemerintah Eks Karesidenan Surakarta). Naskah Publikasi Jurusan Akuntansi Fakultas Ekonomi Dan Bisnis Universitas Muhammadiyah Surakarta, 10(2), 1-22.

Winarsih, K. P., \& Suardana, K. A. (2018). Pengaruh Budaya Organisasi, Independensi, Objektivitas, Akuntabilitas, Dan Pengalaman Kerja Pada Kinerja Pengawas LPD. E-Jurnal Akuntansi, 24(3), 2176-2195.

Yadnya, I. P. P., \& Ariyanto, D. (2017). Pengaruh Kompetensi Dan Independensi Pada Kinerja Auditor Dengan Etika Auditor Sebagai Variabel Moderasi. EJurnal Akuntansi Universitas Udayana, 19(2), 973-999. 